\title{
Carmen Borbély
}

\section{"Their Spidery Self": On Webs of Subject-Object Empathy in Bernardine Gvaristo's fiction}

\begin{abstract}
Drawing on the theoretical premises of Anthropocene feminism, new materialist feminism and empathy studies, this paper represents an attempt to explore the mutually constitutive relations conjured in Bernardine Evaristo's fiction between subjects and the object worlds they inhabit. Focusing on Lara (1997) and Girl, Woman, Other (2019) as examples of "fusion fiction," the paper explores the ways in which a composite sense of agency is articulated between the human and the nonhuman, shaping what feminist thinkers from Rosi Braidotti to Jane Bennett envision as our posthuman horizons.
\end{abstract}

Keywords: Self; Other; Empathy; Nonhuman Agency; Composite Ontologies.

\section{CARMEn BorbéLY}

Babeș-Bolyai University, Cluj-Napoca, Romania carmen.borbely@ubbcluj.ro

DOI: $10.24193 /$ cechinox.2021.41.22
\ 7 hen, in November 2019, the Booksplit the award between two women authors, Margaret Atwood, whose Testaments was becoming a fast-selling sequel to her feminist dystopia The Handmaid's Tale, and Bernardine Evaristo, whose Girl, Woman, Other made her the first female Black British author to have received this accolade, the Anglo-Nigerian writer rejoiced in being declared co-winner alongside an author whose feminist concerns she shared and whose speculative imagination she had praised in her review of the 2009 The Year of the Flood, a prescient novel about a global pandemic wiping out the human race. ${ }^{1}$ Intriguingly, however, the title of an interview given by Evaristo at the time suggestively claimed the prize was, in fact, to be "shared by the 12 Black Brits," "mostly women aged 19-93, whose lives are somewhat interwoven" in the dense textures of the novel. ${ }^{2}$ Testing the boundaries of narratological conventions, the interviewer's statement blatantly flattened out author-character-narrator distinctions yet, at the same time, it somehow made sense in 
light of the highly experimentalist vein of contemporary feminist life-writing. ${ }^{3}$ This, as Jennifer Cooke shows, is co-extensive with an affective turn in (auto)biographical works and propels an implosion of generic borders, ${ }^{4}$ distributing the focalising nodes across a network of subjectivities in ceaseless need for self-expression.

In this paper, which considers the issue of the composite subject-object ontologies in Evaristo's first and latest verse novels, the theoretical framework derives from Richard Grusin's concept of Anthropocene feminism. ${ }^{5}$ Taking its cue from Donna Haraway's salient attention in her "Cyborg Manifesto" to the coextensivity of natureculture, ${ }^{6}$ Grusin's term brings together the insights of ecofeminism, new materialist feminism and posthumanism to rethink our stance on and "concern for the nonhuman world"7 in such a way as to avoid "enforcing hierarchical dualisms between dominant and oppressed entities." ${ }^{8}$ The feminist posthumanities advocated by Cecilia Åsberg and Rosi Braidotti similarly point out the potential of Evaristo's versified fiction to expose the perils of binarisms by refiguring identity via a "multitude of situated perspectives" versal relations, nomadic subjectivities, and multi-directional transpositions." ${ }^{10}$ Conceptualisations of identity as relational are also articulated on the Latourian notion of a shared moral economy in which the nonhuman impresses upon the human the necessity of an ethical positioning towards the other in a world whose materiality "vibrates," as Jane Bennett suggests, reminding us of the "strange ability of ordinary, man-made items to exceed their status as objects and to manifest traces of independence or aliveness, constituting the outside of our own experience." 11 The "liveness" of matter Bennett champions as integral to the perspective of distributed agency among the human and the nonhuman also pertains directly to the "affective entanglements" that may provide a reciprocally constitutive framework for subject and object, ${ }^{12}$ since, according to empathy theorists like Gregory Currie, it is natural for "ordinary everyday non-sentient things" to elicit human emotion and to produce models that may, in turn, structure "our relations to the external world" and to other humans. ${ }^{13}$

From her debut text Lara, a versified autobiografiction (1997), to her latest oeuvre Girl, Woman, Other (2019), the works of Bernardine Evaristo have been seen to stage a feminist politics of "dissensus" against the burden of dis- and re-location, of identity fracture and recomposition experienced by women in the Black diaspora. ${ }^{14}$ Within the hermeneutic framework set by Arana and Ramey in their post-millennial survey of Black British writing, Evaristo's fiction - including, for instance, The Emperor's Babe, a "verse novel" about a Nubian poetess building her selfhood in ancient Roman London ${ }^{15}$ - appears to convey a "sense of abiding alienness"16 that has led different generations of Black British women to contest, in distinct ways and to differing degrees, their cultural exclusion and misrepresentation. ${ }^{17}$ Evaristo's creative interests revolve, like those of other Black British writers like Jackie Kay, Zadie Smith, Andrea Levy and Helen Oyeyemi, around the diasporic fate of individuals exposed to nostalgic impossibilities of return to homelands that are still devastated by the after-effects of colonialism or of different generations of migrants coping with varying forms of vulnerability in Britain. 
Commenting on the intricate, intermeshed trajectories that have energised the flowing rhythms of her fiction, Evaristo, a prose writer with insuppressibly lyrical tempos and visions, has highlighted the complicated routes that her "poetic concision, compression and imagery" tend to launch across the spacious cartographies of the novel, ${ }^{18}$ as a genre that not only enables, but pushes towards an expansion of focus from isolated individual selves to their relational or affiliative networks, which, as I hope this paper will show, may incorporate not just human but also nonhuman others. ${ }^{19}$

Lara (1997), a "narrative poem" or "verse novel"20 that undercuts the grandiose claims of the bildungsroman, charts the discrete yet interlocking life stories of the title character's forebears, on both her maternal and her paternal sides. Navigating a fluid family history that spans three continents and meanders back and forth across centuries of enslavement and indentured labour, Lara fleshes out a tribute to "the everlasting global reality of cross-pollination as an essential life-enhancing force within all of us. ${ }^{21}$ Despite the genealogical tree Evaristo builds at the beginning of the narrative to explain the complexly intersected lives of Lara's diasporic family, a family subject to numerous translocations and transpositions, the narrative pattern mirrors that of a double-helix, reeling in the cultural and biogenetic concatenations of her ancestry. Fractured and disjointed, Lara da Costa's first-person discourse is filled, as Evaristo puts it in an interview with Karen Hooper, by "multiple voices who take up the story across different time-periods and continents before, in a sense, handing over to other voices, other characters." ${ }^{22}$ The protagonist's nascent consciousness is pictured taking shape from the material sites of memory activated by objects that marked her precursors' existence, as well as from the survival struggles of her mother's and father's lineages: Irish Catholic poor escaping the Great Famine of the 1840s by moving into a largely hostile English environment, German migrants seeking economic relief in late nineteenth-century London, and Yorubas who are exploited on Brazilian plantations, return to a state of penury in Nigeria and migrate to London in the hope of a better life in post-war times. The prologue sets, side by side, the image of "Sugar cane, damp musky earth, saccharine vanilla/ journeys in from Eighteen Forty-Nine, scenting Lara" at present, and the vision of her ravished, ancestress Severina, whose "ruptured body"23 only survives violation attempts by partaking of the animacy of matter:

\section{Severina}

the scarred one. [...] My screams

ricocheted the walls, he ejaculated on my ruptured

body but by them I had become the fire of a naked torch, until he put me out. Then I jumped a spider, crept deftly through the warren of cellars into daylight

where a bird swooped me up. I became that bird,

circled the fazenda until a baobab seed rooted

from my droppings. ${ }^{24}$

As Gregory Currie shows, while "we think of empathy as an intimate, feeling-based understanding of another's inner life," it should also perhaps be envisioned 
"as a way of understanding inanimate objects." 25 In Evaristo's text, object do not simply trigger emotion, they serve as ethical conduits for an affective, responsive immersion into remembrance. Bitter-sweet like the scent that sugar still emanates as a tribute to the labour that was expended for its extraction and as a reminder of its status as a luxury commodity for the colonial elites, the memories of Lara's forerunners are affectively imprinted in her corporeal self, as she learns to empathise with the suffering of all those women - Ellen, Sam's Mama, Peggy, Emma, Caitlin, Mary Jane, Zenobia, Peggy - who, like Severina, drew their vital force from the "nonhuman or not-quite human things" ${ }^{26}$ they shared their existence with. This propensity of nonhuman others to empathise with the human lends itself to comprehension through the conceptual lenses of what new materialist thinkers like Jane Bennett describe as the "vitality of matter," 27 matter whose agency may spur the "emergence of more ecological and more materially sustainable modes of production and consumption," 28 or to what Mel Y Chen defines as the animacy of the animal or object world, with its capacity to "trouble and undo stubborn binary systems of difference, including dynamism/stasis, life/death, subject/object, speech/nonspeech, human/animal, natural body/cyborg." 29

Similar human/nonhuman interconnectivities and animate/inanimate assemblages that call attention to the "capacity of things [...] not only to impede or block the will and design of humans but also to act as quasi agents or forces with trajectories, propensities, or tendencies of their own" 30 complicate the protagonists' genealogical filiations in Evaristo's latest fiction as well, including Girl, Woman, Other. Its generic hybridity is referenced in the author's own concept of "verse fiction" or "fusion fiction," defined as follows:

The characters' lives and stories and interlinked through a literary form I've coined 'fusion fiction' - which employs a pro-poetic patterning on the page and non-orthodox punctuation, while fusing the women's lives together. Each woman has a dedicated chapter, and they interrelate through $\mathrm{x}$-degrees of separation. [...] I loved writing in this form because it allowed me to flow freely - from interiority to exteriority, from the past to the present, from one character's narrative to the next. ${ }^{31}$

While the trope subtending the narrative arc of Lara is the double-stranded genetic code, the one articulating the multitudinous life stories in Girl, Woman, Other is the rhizome, extending its branches laterally rather than vertically, and propagating its vital, generative offshoots almost to infinity. ${ }^{32}$ Lara's twice-folded foray into the past seeks, like the twinned helix of her DNA, to link her own life to the multiply knotted stories of her ancestors' strained lives, as well as to broader colonial or post-colonial histories that simultaneously propel and obscure the prospect of self-knowledge. Sites of intense labour, like the plantations on which her Yoruban paternal great-grandparents toiled or the sugar bakery in which Louis, the German emigree was sickened by the "saccharine" smell, ${ }^{33}$ the kitchen where her maternal great-great grandmother Emma spent "every waking moment" 34 and the moist cellar 
in which she slept as a scullery maid, the foul smell of the windowless London tenement building in which her Irish relatives sought refuge from the famine, or the festering Asylum for the Houseless Poor to which her immigrant relatives were refused access in the late nineteenth century - all these spaces Lara immerses herself via remembrance, and all the objects in them, along with all the tastes, sights and smells they elicit are imaginatively converted into memory devices.

As the novel's subtitle indicates, Lara's name is a contracted form of a Yoruban proverb, Omilara. Translated, its meaning is "The family is like water." The fluid intersections of her own memory with the reconstructed material memories of her family suggest that in Evaristo's fiction, solid, rigid identity patterns are superseded by flexible, extra-territorial figurations in trans-generational time. ${ }^{35}$ Her protagonists, whether we speak of Lara, of Zuleika in The Emperor's Babe, Alice Scagglethorpe in Blonde Roots or Stanley Williams in Soul Tourists, engage with strategies of transposition and transference into plateaus of co-extensivity between self and other. They experience identity (dis)continuities as they are diss- and re-assembled with the material ontologies of the places they inhabit or move through. Put differently, within a Deleuzian frame of reference, these characters resist molar confinement even when they are trapped by the historical contingencies of slavery, migration, or refuge. They live through inescapable de- and reterritorialisations, and their lives are mapped unto assemblages that are, as Deleuze and Guattari show, "open and connectable in all of [their] dimensions," "detachable, reversible, susceptible to constant modification." ${ }^{36}$
Evaristo's 2019 contrapuntal novel is commonly regarded as an endeavour to identify and expose Brexit's "residual ideologies of imperialism" 37 in conjunction with the modes of hospitality afforded to postcolonial migrants in Britain and to draw attention to the myriad possibilities to "revision the nation in a firmly polycultural and international frame, betwixt and between other continents, as a shared rather than subjective concern." ${ }^{38}$ In addition to this, as Sarıkaya-Şen shows in her analysis of Girl, Woman, Other, the novel's "networked structure exposes transtemporal and transnational patterns of diversity, connectedness and relationality, as well as the distinctive genealogy of black British women and their maternal empowerment." ${ }^{39}$ While I agree with Sarıkaya-Şen's conclusions, I also believe that in calling attention to the multiplicity of "others" whose life events - both quotidian and intimate, routine and disruptive, personal and collective - are intersected and blended with the destinies of diasporic multitudes, Evaristo's best-known "fusion fiction" also foregrounds a Latourian compositionist logic, which renders the purity of self-contained ontologies ineffectual, while rethinking the perimeter of selfhood as contiguous with the otherness of human and nonhuman actants. ${ }^{40}$ In Latour's compositionist manifesto, seminal for the notion that subjectivity is an aggregate of "quasi-objects, quasi-subjects," 41 which

have to be put together (Latin componere) while retaining their heterogeneity. Also, it is connected with composure; it has clear roots in art, painting, music, theater, dance, and thus is associated with choreography 
and scenography; it is not too far from "compromise" and "compromising," retaining a certain diplomatic and prudential flavor. Speaking of flavor, it carries with it the pungent but ecologically correct smell of "compost," itself due to the active "de-composition" of many invisible agents. ${ }^{42}$

Praised for its celebration of the manifold webs linking the lived experiences of its protagonists, the text features engagements with the lively materiality of the worlds that they inhabit in ways that are reminiscent of the freshness of vision that modernist aesthetics extolled. A selfavowed "literary experimentalist who loves exploring the possibilities of language," 43 Evaristo has admitted to her earlier "visceral reaction" 44 against a modernist precursor whose London-scaped novel pre-figures many of her own characters' urban perambulations on the day when the premiere of Amma Bonsu's play about Amazons is scheduled to take place. Aligning not just Amma's coursing through the city, but also the reader's access to the many layered plateaus opening up for exploration, the river Thames meanders its way around the capital city's sites of memory. It also the criss-crosses the paths of the twelve women whose life stories will be rounded up in Amma's compositionist representation of Amazons:

\footnotetext{
Amma

is walking along the promenade of the waterway that bisects her city, a few early morning barges cruise slowly by to her left is the nautical-themed footbridge with its deck-like walkway and sailing mast pylons
}

to her right is the bend in the river as it heads east past Waterloo Bridge towards the dome of St Paul's

she feels the sun begin to rise, the air still breezy before the city clogs up with heat and fumes

a violinist plays something suitably uplifting further along the promenade Amma's play, The Last Amazon of Dabomey, opens at the National tonight. ${ }^{45}$

Like the focalising flâneuse of Woolf's Mrs Dalloway, who saunters through multitudes, enrapt by the synergetic and synaesthetic rhythms of modernity, Megan/ Morgan's or Amma's senses - olfactory, aural, visual - produce empathic reactions to this environment. They also forego the intimacies of their monadic selves, experiencing not only alienation at seeing the futuristic architecture or the city-dwellers, but also emergent intersubjective empathies and a burgeoning impulse to relate to other humans:

Morgan had escaped outside, lit a roll-up, a glass of pretentious fake champagne in hand (no down-toearth beers or lagers)

they look over at the overblown buildings on the other side of the river

the usual clashing mish-mash of the capital's monstrosities

Morgan gets lost in this city, their senses assaulted to the point of disorientation by the jumble of high roads and side roads and relentless traffic and the pressure of millions of people walking too fast

who'll mow them down like convoys of unstoppable army tanks crushing their spidery self 
they can't get their head around city-dwellers who complain the countryside looks all the same to them when it's this city that's chaotically confusing. ${ }^{46}$

As focalisation is ceaselessly translocated from narrator to character or from character to the object world around them, it becomes clearer that the "spidery self" Megan/Morgan embraces as a refusal of entrenched identity binarisms also speaks to a more general "capacity to respond to others ethically - enabling us not only to gain a grasp of the other's suffering, but also to respond in an ethically appropriate way." 47 Adamantly self-defining, Megan/ Morgan chooses the arachnid image as a moral corollary of the compositeness of identity, at the interface between self and other, human and nonhuman, animate and inanimate. This compositionist trope of selfhood bespeaks, thus, the meaningful value that the marginal, the "other" of Evaristo's title can convey in fair juxtaposition with all the other figurations of alterity the novel pays homage to. The novel's dedication to

the sisters $\&$ the sistas $\&$ the sistahs $\&$ the sistren

$\&$ the women $\&$ the womxn $\&$ the wimmin \& the womyn

\& our brethren \& our bredrin \& our brothers \& our bruvs

$\&$ our men $\&$ our mandem $\&$ the LGBTQI+ members of the human family $^{48}$

points to a deliberately inclusive politics of (post)gender representation, reflecting the author's intention to encompass and "explore as many black British women as possible in a single novel." ${ }^{49}$ As Evaristo admits,

I wanted to expand the representation of who we are in this country, rather than define it or reduce it. They are aged 19 to 93 and every generation in between, and that was really important. Some of them are migrants who have come from another place. A lot of them are born in Britain, because I wanted to make the point about people who were born here and raised here and this being the only country they know. ${ }^{50}$

Punctuation-free, this intersectional narrative runs lithely, like the river, spanning a timeframe that joins the turn of the twentieth century to the late 2010s, and ranging from the Scottish wilderness to pristine Cornwall, Africa, America and the Caribbean. Sequentially distributed on the page, the stories of Amma, Dominique, Yazz, Carole, Bummi, LaTisha, Shirley, Winsome, Penelope, Megan/Morgan, Hattie and Grace shed light on one another, interconnecting these selves in ways that reveal possible solutions to the ethical conundrum of contemporary writing that seeks to "reconcile the need to move beyond past horrors with the ethico-political need to remember them and reconstruct a black body that might be positively claimed." ${ }^{51}$

Functioning like a system of communicating vessels, Girl, Woman, Other encompasses the intersecting and interfolding life-stories of many women who are visibly or invisibly attached not only to one another, but to a sense of diasporic 
dissemination in the material fabric of the world. Along the lines traced by feminist philosophers such as Rosi Braidotti, the following definition of the posthuman conveys the fluid assemblages of Evaristo's characters:

I define the critical posthuman subject within an eco-philosophy of multiple belongings, as a relational subject constituted in and by multiplicity, that is to say a subject that works across differences and is also internally differentiated, but still grounded and accountable. Posthuman subjectivity expresses an embodied and embedded and hence partial form of accountability, based on a strong sense of collectivity, relationality and hence community building. My position is in favour of complexity and promotes radical posthuman subjectivity, resting on the ethics of becoming. ${ }^{52}$

Braidotti endorses the idea that posthuman subjectivity is not just relational and nonhierarchical, but also averse to human exceptionalism. This position is further nuanced in A Feminist Companion to the Posthumanities, coedited with $\mathrm{Ce}-$ cilia Åsberg, which underlines the way in which "people are entangled in co-constitutive relationships with nature and the environment, with other animals and organisms." ${ }^{53}$ This model of posthuman connectivity, Braidotti and Åsberg maintain, can undo the perilous nature/culture divide and also destabilise "a subset of other violent hierarchies, such as wild/civilised, or Universal Man vis-à-vis women, natives, queers, animals, and other Earth Others at large." 54 Braidotti's sense of an "ecological distribution of agency" is indebted to Donna Haraway's Cyborg Manifesto (1985), which, in consonance with Braidotti's new materialist position, claims that human subjectivity must open up to forms of nonhuman consciousness.

In Vibrant Matter. A Political Ecology of Things, Bennett discusses the way in which the human may become a participant in material formations innervated by a composite vitality, conditional upon a nonhegemonic stance on the centrality of human agency in a world where it may be possible to envision

The vitality of (nonhuman) bodies? By "vitality" I mean the capacity of things - edibles, commodities, storms, metals - not only to impede or block the will and designs of humans but also to act as quasi agents or forces with trajectories, propensities, or tendencies of their own. My aspiration is to articulate a vibrant materiality that runs alongside and inside humans. ${ }^{55}$

For the human to sense the vibrancy of matter would entail surrendering the drive to command objects from a hegemonic vantage point and, in Bennett's words, to parse "the world into dull matter (it, things) and vibrant life (us, beings). ${ }^{56}$ It would also mean opting for immersion within hybrid assemblages of human and nonhuman actants that catalyse distributive forms of agency as an alternative to artificial subject-object dichotomies. ${ }^{57}$ The way Latour describes the "conceptual scenography for the pair human and nonhuman" 58 and their reciprocal foldings into "constantly changing collectives" 59 aptly captures the intersecting webs of 
subject-object empathy in Evaristo's novels. Because of space constraints, I will limit my argument to two examples.

Much of the novel's concern with the way in which matter buttresses a sense of individual and collective identity taps into the potential of food to activate a communal memory of rhizomatic traces that are distributed across the diasporic space. Upon celebrating Amma's fiftieth birthday, the members of the cast draw around her kitchen table in Brixton, sharing "the dishes each one has brought: chickpea stew, jerk chicken, Greek salad, lentil curry, roasted vegetables, Moroccan lamb, saffron rice, beetroot and kale salad, jollof quinoa and gluten-free pasta for the really irritating fusspots." ${ }^{60}$ The city's kitchens, pantries, markets and tables filled with victuals become loci of a vibrant cultural memory that blends past and present, near and afar, self and other. Wives rush to lay the patriarchs' dinner, women take menial jobs peddling street food to get by, protest the gentrification of market places that no longer feature "stalls selling parrot fish, yam, ackee, Scotch bonnet peppers, African materials, weaves, Dutch pots, giant Nigerian land snails and pickled green eggs from China," ${ }^{11}$ or develop, like Carole, a class-consciousness of culinary appropriateness, as they moves up the social ladder.

The most telling episode concerning the potential of (edible) matter to furnish a sense of agency to the human occurs when Carole's mother, Bummi, a Nigerian immigrant who obtained a mathematics degree in her home country but is now forced to clean offices for a living, protests against her daughter's disconnection from her culture by showing her a "supersize sack of Basmati rice she'd bought in the Bangladeshi minimart on the high street that was twenty times cheaper than the small-small packets of rice sold in the rich people's supermarket at the corner." ${ }^{2}$ The women's affective response to this seemingly ordinary, yet critical life event is condensed in the empathic, or rather empathet(h)ic response that humble matter trigger and instils in humans, in keeping with Gregory Currie's thesis that objects may cultivate the subject's "empathy-as-imaginative-exploration" of the other. ${ }^{63}$ For Bummi, taking the time to pluck out the bad grains is a gesture of recognition for the human labour that went into planting and harvesting the rice, a sense of consistency, through time, with the dietary customs of her homeland and a validation of her resistance against the inhuman drive of capital that locks people like her daughter into meaningless patterns of consumption and commodification:

you see here, Bummi said, gesturing at the sack of rice, English people like to waste their money in expensive supermarkets on overpriced goods in fancy packaging, and then dare to complain in the bus queue about the economy going down the drain while giving me filthy looks, when it is them, yes, them who are going down the drain with their susceptibility to fancy advertising that causes a slump in their personal finances as a consequence $[. .$. my point is that you are a Nigerian no matter how high and mighty you think you are no matter how English-English your future husband no matter how English-English you yourself pretend to be 
what is more, if you address me as Mother ever again I will beat you until you are dripping wet with blood and then I will hang you upside down over the balcony with the washing to dry. ${ }^{64}$

By the time Bummi finishes her exhortation, Carole is drenched in tears, ready to reconcile with her mother and with her past. For her, the sack of rice is an economic mode of acquiring the moral lesson imparted to her. It also works as an imperative to self-redefinition. Bill Brown's distinction between objects and things is functional in this context. While objects are pliant and compliant to human will, which means their cultural and social work passes unnoticed, things - in other words, unmanageable objects that jam production or transactional circuits - arrest our attention and sensibly command our consciousness. ${ }^{65}$ As long as it rested in the kitchen as a container of food, Bummi's sack of rice remained an everyday object organically and, hence, invisibly cathected to her livelihood. As soon as the thingness of the sack comes to the fore as an item of transgenerational dispute, it quickens Bummi's memory of her father's plot of land which used to produce indigenous crops like cassava and yam but became unfarmable because of the oil seepages in the Niger Delta. The fuel harvested in the Nigerian marshlands to meet ever growing consumption needs polluted the air and waters, killed the local fish populations and drove the indigent, starving natives into exodus. This is a memory of the precarity of nonhuman and human existence. Prompted by an ordinary sack of rice, this memory is passed from mother to daughter also by way of a commentary on the manifold intersections between local and global predicaments in the anthropogenic age.

The references to difference subsumed by the title of Bernardine Evaristo's novel are further compounded in the collective assemblage of the Amazons, the protagonists of the play authored by Amma. As figures of otherness, Amazons embody a host of paradoxes. To start with, their extraordinary anatomies are redesigned for martial combat through bodily regimens of simultaneous excess and lack. Vulnerable to injury and mutilation, yet hardened so as to become indomitable in battle, their bodies condense the contradictions inherent in what Marina Warner calls the unruly, untamed nature of "elemental she-monsters" like the Hydra, the Melusine or the Medusa, ${ }^{66}$ which threaten to destabilise patriarchy through their corporeal aggregates of femaleness and maleness. Moreover, as Harding states, the strenuous physical exertions and right breast excisions that these fierce warrior women undergo render them fit for "manly" activities and pursuits. ${ }^{67}$ Amazons also straddle the rift between myth and attested history and are deemed by ancient authors like Homer, Herodotus or Strabo to represent an alterity that is as multifaceted as it is unsupressable. ${ }^{68}$

Paradoxically, the empathet(h)ic pull of matter is nowhere less visible than in the artistic project that innervates the feminist energies and political sensibilities of the women, girls and others in Evaristo's text. As seen above, Amma, the radical activist who has spent a lifetime championing the Black British women's cause by either disrupting the workings of a theatre establishment that worked to exclude them or by staging the fifteen fringe dramas she 
has written and produced, is finally on the brink of achieving recognition when her plays, The Last Amazon of Dahomey, is about to be mounted at the National Theatre. Its after-party gathers together multitudes, including the selves who have been others to the storytellers thus far. Inspired by a story of Yoruban female emancipation, according to which the Amazons of the Bay of Benin were former royal slaves whose martial skills allowed them to form an army for protecting the realm against the French colonists, ${ }^{69}$ the play - which finds another rendition in Bummi's dream of saving the planet with her legions of cleaners ${ }^{70}$ - is a sweeping success with both the mainstream critics and the public, although it does get criticised for its overly realistic representation:

perhaps the play could also have employed even more techno-dramatic devices in its production such as holograms of the original Amazons of Greek myth hovering as peripheralized spectres counterpointing the main drama thereby adding a more classical relevancy to its thesis? [...] nevertheless, as for the wash of images projected on to the stage making it appear to be filled with thousands of dead Benin Amazons stampeding towards the audience brandishing weaponry and uttering war cries it was terrifyingly realistic and without doubt a coup de théâtre. ${ }^{71}$

Intriguingly, the stage is devoid of any props or other paraphernalia that might have simulated in any way an attempt at a realistic rendition of the plot. The actresses' costumes are acquired from second-hand shops, the sets are extracted from junk yards and rehearsals take place in living rooms. There is a sense that matter somehow either absconds itself in Amma's about to be enacted play, or on the contrary, that it marks a refusal of the remainder stuff, the discarded detritus of a consumerist society - to disappear, to derealise itself. Either way, if we look at the contemporary props of Amma's historical play as a reminder of the importance of material anchors of cultural memory, in conjunction with the imagery of remembrance itself (Nawi encountering her former Amazon companions, whose spectral, hologrammatic figures fade in and out of the field of vision), one might say, following Latour's understanding of composite agency, that Evaristo's protagonists renounce the phantasm of insulated individualism and become networked across densely tangled aggregates of objects and subjects. This figure of the Amazon collective, resurrected with every new performance, echoes Haraway's analogy between the cyborg and the feminist body politic:

cyborg politics insist on noise and advocate pollution, rejoicing in the illegitimate fusions of animal and machine. These are the couplings which make Man and Woman so problematic, subverting the structure of desire, the force imagined to generate language and gender, and so subverting the structure and modes of reproduction of "Western" identity, of nature and culture, of mirror and eye, slave and master, body and mind. ${ }^{72}$

In a "post-gender," "posthumanist" world, ${ }^{73}$ such as the one configured by 
Evaristo in her latest fiction, the politics of identity would entail a pollution of all boundaries, making the abjection of otherness, as a strategy of self-definition, irrelevant.
Instead, the webs of empathy that cut across binarisms realign human and nonhuman life within emergent ecologies of materiality that shape our posthuman horizon.

\section{BibLIOGRAPHY}

Ahern, Stephen (ed.), Affect Theory and Literary Critical Practice. A Feel for the Text, Palgrave Macmillan, 2019. Alpern, Stanley B., Amazons of Black Sparta. The Women Warriors of Dahomey, New York, New York University Press, 1998.

Arana, R. Victoria and Lauri Ramey. "Introduction." Black British Writing, edited by R. Victoria Arana and Lauri Ramey, Palgrave MacMillan, 2004, pp. 1-8.

Åsberg, Cecilia and Rosi Braidotti, "Feminist Posthumanities. An Introduction,” in Cecilia Åsberg and Rosi Braidotti (eds.), A Feminist Companion to the Posthumanities, Springer, 2018, pp. 1-22.

Bennett, Jane, Vibrant Matter. A Political Ecology of Things, Durham and London, Duke University Press, 2010.

Braidotti, Rosi, The Posthuman, Cambridge, Polity Press, 2013.

Chen, Mel Y., Animacies. Biopolitics, Racial Mattering, and Queer Affect, Durham and London, Duke University Press, 2012.

Collins, Michael, "My Preoccupations Are in My DNA': An Interview with Bernardine Evaristo," Callaloo, vol. 31, no. 4, 2008, pp. 1199-1203.

Cooke, Jennifer, Contemporary Feminist Life-Writing. The New Audacity, Cambridge, Cambridge University Press, 2020.

Coplan, Amy and Peter Goldie (eds.), Empathy. Philosophical and Psychological Perspectives, Oxford, Oxford University Press, 2011.

Courtois, Cédric, "Bernardine Evaristo's 'Black' British Amazons: Aesthetics and Politics in Girl, Woman, Other (2019)," Études britanniques contemporaine, no. 60, 2021, OpenEdition Journals, https://doi. org/10.4000/ebc.10651, accessed 31 March 2021.

Currie, Gregory, "Empathy for Objects," in Amy Coplan and Peter Goldie (eds.), Empathy. Philosophical and Psychological Perspectives, Oxford, Oxford University Press, 2011, pp. 82-98.

Deleuze, Gilles and Félix Guattari, A Thousand Plateaus. Capitalism and Schizophrenia, translated by Brian Massumi, London and New York, Continuum, 1987.

Evaristo, Bernardine, "It's shocking that people don't understand Britain's involvement in slavery," Interview with Amelia Gentleman, The Guardian, https://www.theguardian.com/books/2020/ jun/19/bernardine-evaristo-its-shocking-that-people-dont-understand-britains-involvement-inslavery, 19 June 2020, accessed 18 October 2020..

Evaristo, Bernardine, "On the Road: Bernardine Evaristo interviewed by Karen Hooper," Journal of Commonwealth Literature, vol. 41, no. 1, 2006, pp. 3-16.

Evaristo, Bernardine, "Review: The Year of the Flood," Financial Times, 5 September 2009, https://www. ft.com/content/7a12aeca-98e5-11de-aa1b-00144feabdc0.

Evaristo, Bernardine, “The Essay. Open Endings. Bernardine Evaristo on Mrs Dalloway," BBC Sounds https://www.bbc.co.uk/sounds/play/m000cm9s, accessed 15 September 2019.

Evaristo, Bernardine, Girl, Woman, Other, London, Penguin, 2019.

Evaristo, Bernardine, Manifesto. On Never Giving Up, London, Penguin, 2021, Kindle edition.

Evaristo, Bernardine, Lara, Glasgow, Northumberland, Bloodaxe Books, 1997.

Evaristo, Bernardine, The Emperor's Babe (2001), London, Penguin Books, 2020.

Grusin, Richard, "Introduction. Anthropocene Feminism: An Experiment in Collaborative Theorising," in Richard Grusin (ed.), Anthropocene Feminism, Minneapolis and London, University of Minnesota Press, 2017, pp. vii-xix. 
Haraway, Donna J., "A Cyborg Manifesto: Science, Technology, and Socialist-Feminism in the Late Twentieth Century," in Simians, Cyborgs, and Women. The Reinvention of Nature, New York, Routledge, 1991, pp. 149-182.

Hardwick, Lorna, “Ancient Amazons - Heroes, Outsiders or Women?” Greece E Rome, vol. 37, no. 1, 1990, pp. 14-36.

Koegler, Caroline, Pavan Kumar Malreddy \& Marlena Tronicke. "The colonial remains of Brexit: Empire nostalgia and narcissistic nationalism.” Journal of Postcolonial Writing, vol. 56, no. 5, 2020, pp. 585-592.

Latour, Bruno, "An Attempt at a 'Compositionist Manifesto'," New Literary History, 2010, 41, pp. 471-490.

Latour, Bruno, Pandora's Hope. Essays on the Reality of Science Studies, Cambridge, MA and London, Harvard University Press, 1999.

Latour, Bruno, We Have Never Been Modern, translated by Catherine Porter, Cambridge, Massachusetts, Harvard University Press, 1993.

McLeod, John. "Extra Dimensions, New Routines.” Wasafiri, vol. 25, no. 4, 2010, pp. 45-52.

Sarıkaya-Şen, Merve. "Reconfiguring Feminism: Bernardine Evaristo's Girl, Woman, Other," The European Legacy, vol. 26, no. 3-4, 2021, pp. 303-315, accessed 28 March 2021.

Scott, Simon, "The Booker Prize Is Shared by the 12 Black Brits In 'Girl, Woman, Other'," NPR, 9 November 2019, https://www.npr.org/2019/11/09/777616750/the-booker-prize-isshared-by-the-12-black-brits-in-girl-woman-other?t=1635058435953.

Upstone, Sara, "Black British Fiction," in Daniel O'Gorman and Robert Eaglestone (eds.), The Routledge Companion to Twenty-First Century Literary Fiction, New York, Routledge, 2019, pp. 125-135.

Warner, Marina, Managing Monsters. Six Myths of Our Time. The Reith Lectures 1994, New York, Vintage, 1994.

\section{NoTES}

1. Bernardine Evaristo, "Review: The Year of the Flood," Financial Times, 5 September 2009, https://www. ft.com/content/7a12aeca-98e5-11de-aa1b-00144feabdc0, accessed 4 March 2021.

2. Scott, Simon, “The Booker Prize Is Shared by the 12 Black Brits In 'Girl, Woman, Other'," NPR, 9 November 2019, https://www.npr.org/2019/11/09/777616750/the-booker-prize-is-shared-bythe-12-black-brits-in-girl-woman-other?t=1635058435953, accessed 12 October 2020.

3. Jennifer Cooke, Contemporary Feminist Life-Writing. The New Audacity, Cambridge, Cambridge University Press, 2020.

4. Ibidem, p. 8.

5. Grusin, Richard, "Introduction. Anthropocene Feminism: An Experiment in Collaborative Theorising," in Richard Grusin (ed.), Anthropocene Feminism, Minneapolis and London, University of Minnesota Press, 2017, p.

6. Donna J. Haraway, Simians, Cyborgs, and Women. The Reinvention of Nature, New York, Routledge, 1991, p. 11.

7. Richard, "Introduction," p. xi.

8. Ibidem, p. ix.

9. Åsberg, Cecilia and Rosi Braidotti, "Feminist Posthumanities. An Introduction," in Cecilia Åsberg and Rosi Braidotti (eds.), A Feminist Companion to the Posthumanities, Springer, 2018, p. 18.

10. Ibidem, p. 16.

11. Jane Bennett, Vibrant Matter. A Political Ecology of Things, Durham and London, Duke University Press, 2010, p. xvi.

12. Ahern, Stephen (ed.), Affect Theory and Literary Critical Practice. A Feel for the Text, Palgrave Macmillan, 2019, p. 153. 
13. Amy Coplan and Peter Goldie (eds.), Empathy. Philosophical and Psychological Perspectives, Oxford, Oxford University Press, 2011, p. xxxviii.

14. Cédric Courtois, "Bernardine Evaristo's 'Black' British Amazons: Aesthetics and Politics in Girl, Woman, Other (2019)," Études britanniques contemporaine, no. 60, 2021, OpenEdition Journals, https://doi.org/10.4000/ebc.10651, accessed 31 March 2021.

15. Bernardine Evaristo, Manifesto. On Never Giving Up, London, Penguin, 2021, Kindle edition.

16. R. Victoria Arana and Lauri Ramey. "Introduction." Black British Writing, edited by R. Victoria Arana and Lauri Ramey, Palgrave MacMillan, 2004, p. 3.

17. Ibidem, pp. 4-5.

18. Evaristo, Manifesto, ibidem.

19. Ibidem.

20. Ibidem.

21. Ibidem.

22. Bernardine Evaristo, “On the Road: Bernardine Evaristo interviewed by Karen Hooper," Journal of Commonwealth Literature, vol. 41, no. 1, 2006, p. 7.

23. Bernardine Evaristo, Lara, Glasgow, Northumberland, Bloodaxe Books, 1997, p. 16.

24. Ibidem.

25. Gregory Currie, "Empathy for Objects," in Amy Coplan and Peter Goldie (eds.), Empathy. Philosophical and Psychological Perspectives, Oxford, Oxford University Press, 2011, p. 82.

26. Bennett, op. cit., p. ix.

27. Ibidem, p. ix.

28. Ibidem.

29. "Animacy $[\ldots]$ has been described variously as a quality of agency, awareness, mobility and liveness," in Mel Y. Chen, Animacies. Biopolitics, Racial Mattering, and Queer Affect, Durham and London, Duke University Press, 2012, p. 2.

30. Bennett, Vibrant Matter, pp. 9-10.

31. Evaristo, Manifesto, ibidem.

32. As Deleuze and Guattari state, rhizomes encapsulate "principles of connection and heterogeneity: any point of a rhizome can be connected to anything other, and must be. This is very different from the tree or root, which plots a point, fixes an order." In A Thousand Plateaus. Capitalism and Schizophrenia, translated by Brian Massumi, London and New York, Continuum, 1987, p. 7.

33. Evaristo, Lara, p. 16.

34. Ibidem, p. 45.

35. See Deleuze and Guattari, op. cit., pp. 55-58.

36. Ibidem, p. 13.

37. Caroline Koegler, Pavan Kumar Malreddy and Marlena Tronicke, "The colonial remains of Brexit: Empire nostalgia and narcissistic nationalism," Journal of Postcolonial Writing, vol. 56, no. 5, 2020, p. 589.

38. John McLeod, “Extra Dimensions, New Routines," Wasafiri, vol. 25, no. 4, 2010, p. 48.

39. Merve Sarıkaya-Şen, "Reconfiguring Feminism: Bernardine Evaristo's Girl, Woman, Other," The European Legacy, vol. 26, no. 3-4, 2021, p. 303.

40. Bruno Latour, "An Attempt at a 'Compositionist Manifesto'," New Literary History, 2010, 41, pp. 471-490.

41. Bruno Latour, We Have Never Been Modern, translated by Catherine Porter, Cambridge, Massachusetts, Harvard University Press, 1993, p. 51.

42. Latour, "An Attempt," pp. 473-474.

43. Bernardine Evaristo, "The Essay. Open Endings. Bernardine Evaristo on Mrs Dalloway," $B B C$ Sounds https://www.bbc.co.uk/sounds/play/m000cm9s, accessed 15 September 2019.

44. Evaristo, Manifesto, ibidem.

45. Bernardine Evaristo, Girl, Woman, Other, London, Penguin, 2019, p. 1. 
46. Ibidem, pp. 329-330.

47. Coplan and Goldie, op. cit., p. ix.

48. Evaristo, Girl, Woman, Other, front page.

49. Bernardine Evaristo, "It's shocking that people don't understand Britain's involvement in slavery," Interview with Amelia Gentleman, The Guardian, https://www.theguardian.com/books/2020/ jun/19/bernardine-evaristo-its-shocking-that-people-dont-understand-britains-involvement-inslavery, 19 June 2020, accessed 18 October 2020.

50. Ibidem.

51. Sara Upstone, "Black British Fiction," in Daniel O'Gorman and Robert Eaglestone (eds.), The Routledge Companion to Twenty-First Century Literary Fiction, New York, Routledge, 2019, p. 132.

52. Rosi Braidotti, The Posthuman, Cambridge, Polity Press, 2013, p. 49.

53. Åsberg and Braidotti, op. cit., p. 1.

54. Ibidem, p. 2.

55. Bennett, Vibrant Matter, p. viii.

56. Ibidem, p. vii.

57. Bruno Latour, Pandora's Hope. Essays on the Reality of Science Studies, Cambridge, MA and London, Harvard University Press, 1999 , p. viii.

58. Ibidem.

59. Ibidem, p. 16.

60. Evaristo, Girl, Woman, Other, p. 4.

61. Ibidem, p. 32.

62. Ibidem, p. 157.

63. Currie, op. cit., p. 86.

64. Evaristo, Girl, Woman, Other, pp. 157-158.

65. Brown, Bill, "Thing Theory," in Critical Inquiry, 28 (1): 2001, pp. 1-22.

66. Marina Warner, Managing Monsters. Six Myths of Our Time. The Reith Lectures 1994, New York, Vintage, 1994, p. 5.

67. Lorna Hardwick, "Ancient Amazons - Heroes, Outsiders or Women?" Greece E Rome, vol. 37, no. 1,1990, p. 18.

68. Stanley B. Alpern, Amazons of Black Sparta. The Women Warriors of Dahomey, New York, New York University Press, 1998, p.7.

69. According to Alpern, the "women soldiers of Dahomey" were "the only thoroughly documented amazons in world history," op. cit., p. 11.

70. Evaristo, Girl, Woman, Other, p. 171.

71. Ibidem, p. 409.

72. Haraway, op. cit., 176.

73. Ibidem, p. 150. 